\title{
INTERNATIONAL TELEPHONE CALLS: GLOBAL AND REGIONAL PATTERNS ${ }^{1}$
}

\author{
Risa Palm ${ }^{2}$ \\ College of Arts and Sciences \\ University of North Carolina, Chapel Hill
}

\begin{abstract}
This study examines patterns in international telephone communications, documenting a close relationship between international call volume aggregated by nation and indicators of global connectivity including volume of international trade, tourism and migration. In addition, the analysis documents the existence of a set of national "communities" of callers. The clear orientation of large portions of the world to former colonial powers (e.g., West Africa and North Africa to France), and the separation of the Muslim Middle East and the Chinese-speaking nations of East and Southeast Asia from other calling communities suggest the importance of continuing historic and cultural influences on information flows.
\end{abstract}

Key words: international telecommunication, telephone traffic, information flows, international connectivity.

\section{TELECOMMUNICATIONS AND GLOBALIZATION}

A burgeoning literature on "globalization" has documented the impact of changing levels of international trade, migration and telecommunications on national governments, local culture, and economic organization (Castells, 1989; Dicken, 1998; Harvey, 1989; Jameson, 1991; Kelly, 1999; Thrift, 1995; Wheeler et al., 2000; Graham and Marvin, 2001). Globalization implies not only control of economic activities by distant entities, but also a changing pattern of flows: of money, ideas, messages and people.

Globalization has not affected the world evenly, but is instead a process with a complex spatial outcome (Collinson, 1999; Kelly, 1999; Mittleman, 1996; Thrift, 1995). New technologies have a highly selective impact on portions of society within nations and on nations within the world. As Dicken (1998, p. 6) put it:

The particular character of individual countries, of regions and of localities interacts with the larger-scale general processes of change to produce quite specific out- comes. Reality is far more complex and messy than many of the grander themes and explanations tend to suggest.

\footnotetext{
${ }^{1}$ I would like to thank Jim Wheeler and Dick Soloway for their encouragement, Rick Peterson and Ed Raison for their help with the figures, and Dee Reid and several anonymous reviewers for their comments on earlier drafts of this manuscript.

2 Correspondence concerning this article should be addressed to Risa Palm, Dean, College of Arts and Sciences, University of North Carolina, Chapel Hill, NC 27599-3100; telephone: 919-962-1165; fax: 919-962-

2408; e-mail palmr@email.unc.edu
} 
Johnston et al. (1995, p. 230) noted the resilience of local cultures to this increased complexity of messages: "Cultural complexity stands less as a monument to the final annihilation of space than as a testament to the complex mappings between force fields of local and global provenance." Cultural differences in governance, trade and research practices even persist in transnational corporations (TNCs) as these entities adjust to their new environments while at the same time introducing practices learned from the corporate home base (Pauly and Reich, 1997; Dicken, 1998).

This paper attempts not only to describe telephone communication patterns at an international scale, but also to point out commonalities and complexities in these patterns, as well as implications for understanding the new and emerging culture regions of the globe. Based on the previous literature on the role of telecommunications in facilitating new forms of international economic organization, this empirical study tests three hypotheses concerning the pattern and structure of international telephone calls. The first is almost a definitional hypothesis on the nature of globalization and the role of telecommunications: that empirically the volume of international telephone traffic is closely related to other indicators of economic connectivity, primarily trade, migration and tourism. This hypothesis is tested with the total volume of telephone calls per nation as well as the volume of calls per capita.

The second hypothesis concerns the structure of national communications relation- ships: that nations can be organized into a hierarchy based on the sending and receiving of telephone calls, with a small number of regional and global centers sending and receiving greater numbers of calls. Those nations with greater influence on the international economy (with higher levels of trade or gross national product, for example) send and receive more calls than those nations that are less international in orientation, regardless of population size.

The third hypothesis is that, despite an extraordinarily large volume of international trade and tourist exchange, there remain distinct cultural regions that can be delimited on the basis of their calling partners. Instead of a pattern that is so complex that all nations are connected to all others, a small number of "calling communities" or circles exists that defines a kind of cultural and therefore economic regionalization of the globe.

\section{RESEARCH RELATED TO THE CURRENT STUDY}

The two geographic studies closest methodologically to the one described in this paper are the analyses of information flows among major metropolitan centers in the United States based on proprietary Federal Express data (Wheeler and Mitchelson, 1989; Mitchelson and Wheeler, 1994). In the 1989 paper, the authors analyzed a 48-by-48 metropolitan area matrix to identify patterns of common inter-city flows, confirming the hypotheses that a small number of command-and-control centers originate a large proportion of information flows, and that distance or the spatial distribution of destinations were unrelated to the volume of flows. The authors used principal components analysis to identify five flow patterns centered on New York, Los Angeles, 
Chicago, Atlanta and Dallas-Fort Worth. In the second paper, the authors analyzed a 47-by-47 city matrix of domestic flows and a 47-by-10 city matrix of international export flows to show concentrated channels of information flow. New York City dominated both the domestic and international flow hierarchy. The current study uses some of the same methodologies as the Wheeler and Mitchelson work, but its focus on national-level telephone contacts introduces complex issues about the impacts of language and culture on flow volumes, and the impacts of extreme differences in resources and infrastructure on access to telecommunications.

Two other studies are related empirically to the one reported in this paper, that is, each analyzed volumes of international telephone communications. A series of studies by Kellerman (1990, 1992) analyzed outgoing telephone calls from a set of 18 countries as well as the exchange of calls among the most industrialized nations - the Group of Seven (G77) - over the period from 1977 to 1987. By examining the percentage of outgoing calls directed at particular nations or sets of nations, Kellerman divided international telephone traffic into three patterns: the first centered on the G7 countries, the second with strongest linkages among neighboring countries and those with linguistic and cultural similarities, and the third based on contacts with previous colonial powers. He also found that among the G7 countries, the percentage of exports going to each of the other G7 countries was the variable most closely correlated with the percentage of outgoing call volume for all countries except the United States. Here the percentage of tourists visiting the G7 country was more closely related to percentage of outgoing call volume.

The second related study of international telephone calls was that by George Barnett (1999), comparing international telephone calling over the period from 1978 to 1992. The study used network analysis (NEGOPY) to identify "centrality, connectedness and integrativeness" for a set of 85 nations. Barnett concluded that the network of calls became more centralized over this period of time with an increasing amount of information flowing through "core nations," further enhancing their economic preeminence in the world system.

This study differs from the two empirical research projects just reviewed in data and method. The data set used in this paper is more current and comprehensive, and it enables the analysis not only of the interactions among highly industrialized nations, but also among a larger set of nations. In the 10 years since the earlier data were collected, the availability of cellular telephones has burgeoned, and, in addition, the price per minute of contact has dropped. International calls are cheaper, easier to make, of higher quality, and far more common. Current data capture this dramatic increase in international telephone traffic along with the changing patterns of connectivity that new technologies have enabled.

The method of analysis used in this paper also results in the possibility of new insights. The paper analyzes first-order calling patterns for a set of 136 nations and also clusters these nations using statistical commonalities in their calling patterns. This analysis allows an empirical examination of existence and nature hierarchy of influence or, alternatively, the existence of a series of relatively independent "calling communities." 


\section{PRE-CONDITIONS FOR INTERNATIONAL TELEPHONE TRAFFIC}

International telephone traffic requires several antecedent conditions. First, voice telephone contact assumes that the speakers share a common language, with all of the implications of this commonality. Second, the connections require access to equipment and message-delivery systems, and any large volume of such connection also requires a relatively low cost of message exchange. Third, the function and content of message transmission must be appropriate for telephone (as opposed to face-to-face) communication. Finally, personal linkages of residents of nations connected by telephone calls must be strong enough to overcome costs or inconvenience of making an international call.

Cultural Similarities or Personal Relationships in a Common Language Must Pre-Exist for International Phone Calls

Once upon a time all the world spoke a single language and used the same words. (Genesis 11:1)

If all people spoke a single language, international telecommunications would not have to overcome the barrier of different languages and associated cultures. Despite the babble of a multiplicity of languages, however, international telecommunications link people throughout the world in trillions of minutes of calls annually. The story of Babel also has been linked to the various interpretations of and responses to globalization. For example, James R. Lee (2000) interpreted the Biblical story as relevant to the ways in which people interpret world trade or globalization: that differences over globalization are comparable to various groups speaking different languages based on entirely different viewpoints, world views and assumptions. Just as the Tower of Babel resulted in peoples not being able to understand one another, so globalization (the processes of increased contact associated with world trade acceleration) are also interpreted very differently, resulting in clashes and perceived threats to individual cultures.

Of course measures of telephone traffic include not only voice but also fax minutes. Fax traffic is important in business calling routes and in cases where written communication is preferable to oral communication - where communicators do not share a common language or where text documents are needed. Fax traffic is also particularly important where there is a large time difference between the communicators or where multiple character sets make e-mail a less reliable technology. Fax messages have declined as a proportion of total call volume: although faxes accounted for $30 \%$ of the total international call traffic in the mid-1990s, e-mail has largely replaced faxes in many routes and now accounts for about $15 \%$ of the total call volume (TeleGeography, 2000a).

One form of communication that telephone traffic does not measure is the use of the Internet or electronic mail. TeleGeography publishes information in Internet bandwidth, and many of the papers on the geography of the Internet have focused on this measure of connectivity. Although 
it is asserted that bandwidth provides an indicator of actual traffic rates, it is more accurate to say that bandwidth is a measure of total capacity rather than actual message flow. One can certainly measure the density of access to the Internet. For example, Dodge and Shiode (2000) published a paper on Internet "real-estate" by plotting the patterns and densities of IP addresses. Further, traceroutes can be used to check network linkages, "packet loss" (reliability of connection) and speeds of message transmission (Dodge and Kitchin, 2001; Murray and Claffy, 2001; Internet Traffic Report, 2002; Traceroute, 2002). Such empirical analysis (Dodge, 1999) can show how a message sent from an individual server is routed and finally arrives at its destination. An elaborated set of traceroutes for a particular period of time could produce a world map of Internet connectivity that would certainly be of interest, but what we have at present is only a mapping of bandwidth rather than actual traffic flows. As Dodge (2001) put it, "Knowledge of how much data traffic flows between different points on the globe is pretty much non-existent today.... Whoever can crack the problems of getting realistic measurements of global Internet traffic will be ready to bring flow mapping to the next level and fill in a major gap in our current knowledge."

\section{TABLE 1.-COMPARISON OF INTERNET BANDWIDTH AND TELEPHONE TRAFFIC} VOLUMES BY REGION

\begin{tabular}{lcc} 
Region & $\begin{array}{c}\text { World } \\
\text { Internet } \\
\text { bandwidth, } \\
2000(\%)\end{array}$ & $\begin{array}{c}\text { World } \\
\text { telephone } \\
\text { traffic, } \\
1999\left(\frac{\circ}{\circ}\right)\end{array}$ \\
\hline Africa-Asia/Pacific & 0.0 & 2.2 \\
Africa-Europe & 0.0 & 6.0 \\
Africa-Latin America & 0.0 & 0.1 \\
Africa-United States/Canada & 0.1 & 0.1 \\
Asia/Pacific-Europe & 0.1 & 10.3 \\
Asia/Pacific-Latin America & 0.0 & 0.5 \\
Asia/Pacific-United States/Canada & 25.9 & 34.4 \\
Europe-Latin America & 0.1 & 2.6 \\
Europe-United States/Canada & 73.8 & 43.8 \\
\hline
\end{tabular}

That said, one can compare the distribution of interregional Internet bandwidth capacity and telephone traffic based on data assembled in TeleGeography 2001 (TeleGeography, 2001b; Table 1). For both data sets, the volume of telephone traffic and bandwidth capacity between the United States/Canada and Europe is higher than any other flow or capacity. Almost $98 \%$ of the world Internet bandwidth capacity links either Europe and the U.S./Canada or Asia/Pacific and U.S./Canada.

However, although almost three quarters of the total 2000 Internet bandwidth is between U.S./Canada and Europe, only $44 \%$ of the telephone calls are shared between these two regions. 
Telephone traffic as opposed to Internet bandwidth capacity shows a stronger connection with these other pairs of regions including the linkage between Asia/ Pacific and Europe (more than $10 \%$ of the total telephone traffic compared to $0.5 \%$ of Internet bandwidth), and Asia/Pacific and U.S./Canada (more than $34 \%$ of telephone traffic compared with nearly $26 \%$ of Internet bandwidth).

\section{Low Cost of International Telephony and Increased Access to Equipment}

In the past, limited access to equipment and the high cost of telephone tolls were major impediments to the volume of international telephone traffic. This situation has changed dramatically with increased access to equipment, an increase in bandwidth capability, and a steep decline in the cost per call.

Access to equipment and networks has been particularly affected by the presence of many millions of cell or mobile phone subscribers. In portions of the world with few opportunities for fixed networks, cell phones provide an opportunity for telephone connection. Scheeres (2001) estimated that $25 \%$ of all Latin Americans will own a cell phone by the year 2004, vastly exceeding access to fixed-line phones. In Africa, TeleGeography (2001c) noted that new mobile phone lines doubled just in 1999, and the percentage of international traffic from mobile phones in Africa rose from about 6\% in 1989 to over 10\% in 1999 (TeleGeography, 2001b). The major reason TeleGeography gave for increases in mobile phone use is the fact that mobile phones are simply more available in certain parts of the world than fixed-line service. ${ }^{3}$

The cost of international telephone calls has also plummeted. TeleGeography (2001d) attributed this price reduction to a combination of fierce competition among carriers and falling costs of both bandwidth and settlement. The 1996 report of the International Tele- communications Union, Direction of Traffic, reported that the cost of a single "voice path" or link that would permit simultaneous telephone calls fell from $\$ 600,000$ in 1956 to $\$ 2650$ in 1993 and $\$ 1.00$ in 1995 with the TAT-12/13 cable. The cost per minute of an INTELSAT (including operating expenses) was reported as $\$ 0.03$ over the entire range of satellites; “operating expenses per satellite would be much lower so that the cost per minute of an international call over INTELSAT is probably less than U.S. \$0.02 a minute.

Undersea bandwidth has also greatly increased, resulting in further capacity for information transmission (Dumett, 1998). TeleGeography (2001d) noted that in the year 2000 alone, submarine cables increased trans-Atlantic bandwidth by a factor of 12 . In addition, the

\footnotetext{
${ }^{3}$ It should be noted that mobile phones have some limitations, particularly when the quality of the call connection is important. TeleGeography (2001b) surveyed international call quality (signal level, noise, echo path loss, echo path delay, and speech activity), answer seizure ratio (percentage of successful call attempts between a switch and a destination), and post dial delay (length of time needed to establish a connection once the dialer has finished dialing). Relatively high quality service - from the U.K. to the U.S., for example - resulted in an answer seizure ratio of $73 \%$, a post dial delay of 2.8 seconds, and a call quality index of 68.8 (acceptable) in summer 2000. Lower quality service - from the U.K. to Pakistan, for example - had an answer seizure ratio of $19 \%$, a post second delay of 5.7 seconds, and a call quality index of 44.1 (poor).
} 
development of dense wavelength-division multiplexing (DWDM) has greatly increased the capacity of individual cables, further increasing capacity and reducing cost per unit (Hardy, 1999). Hardy noted that DWDM has decreased prices by $25 \%$ per year in the Atlantic market.

With this great expansion of capacity, the cost of an international link is effectively close to zero. What supports prices on many of the competitive routes are simply the local interconnection charges at the origin and termination of the call. TeleGeography (2001b) even suggested that international long distance and local calls may converge in price: "Just as we were going to press, the German regulator helped prove the point by permit- ting Deutsche Telekom to charge just 9 pfennigs per minute for calls to the United States only one pfennig more than a call to the apartment next door."

In sum, the operating costs per minute of telephone traffic are generally unrelated to the distance between the origin and the destination of the call. Charges for international telephone calls have fallen sharply because of a combination of increased access to tele- phone equipment, vastly increased transmission capacity, and decreases in regulation of settlement costs.

\section{Use of Telephone Calls as Opposed to Other Forms of Communication}

Sociological and psychological studies have suggested important differences in the uses and effectiveness of the telephone and face-to-face communication. The latter presents both nonverbal and verbal sources of information, which suggests that the use of the tele- phone would have particular functions and shortcomings compared with a personal meeting. Many studies have documented that telephone communication tends to be both more routine and more useful for the one-way communication of orders or information than for more complex, two-way negotiation (Morley and Stephenson, 1977; Argyle et al., 1968). For those speakers not previously acquainted, telephone contact creates greater psychological distance than a face-toface encounter (Short et al., 1976). Rutter (1987) tested the implications of the idea that the telephone is a "cueless" medium wherein only the voice and spoken words are available to communicate and negotiate as opposed to the wide range of nonverbal cues in the personal encounter. It is this "cuelessness" that increases psychological distance, with concomitant impacts on content of the message, style of the encounter, dependence on traditional role relationships, and outcome of the discussion.

The research on the impacts of voice-only communication on the quality of negotiation suggests limitations on the business uses of international telephone calls. Clearly, the telephone can be used effectively to communicate task-oriented directions and information. One can arrange meetings on the telephone, and renew contacts where they have already been established. But the telephone is less effective as a medium for more complex negotiations, particularly when the parties are not previously well acquainted. These limitations suggest that international business telephone calls serve particular, sometimes routine, functions, a fact affecting the pattern and volume of international telephone traffic within and among transnational corporations. 


\section{Migration and Telephone Traffic}

International telephone traffic is also augmented by the migration that has resulted from global economic integration. Migrants across national boundaries keep in touch with friends and family at home, and increased travel and immigration increase the volume of telephone traffic in and of themselves.

Collinson (1999) elucidated the relationship between globalization, migration and, by implication, international telecommunication. Although globalization and migration are related, this relationship is neither simple nor necessarily direct. Migration is always a complex decision on the part of the migrant, and globalization may both increase the level of migration by increasing perceived opportunities in far-flung destinations and also dampen tendencies to migrate as capital follows low-cost labor in situ. Collinson classified three types of international migration: (1) global migration, the movement of people created by the new structures and processes in the world political economy, including world tourism; (2) commercial and worker migration, that movement of workers facilitated by agreements between states, and (3) "transnational" migration which includes worker migration, family and refugee migration, movements related to territorial forces rather than those facilitated by TNCs or supported by global capital. Clearly, global migrants - whether executives moving to another corporate site to carry out a limited assignment or individuals and families involved in global tourism - are likely to keep in close contact with their home and corporate headquarters, generating large amounts of telephone traffic. Commercial and worker migration also connotes a temporary movement of workers, maintaining home relationships and therefore close ties with the country of origin. Finally, individuals involved in transnational movement - whether due to political or economic push-and-pull forces, refugee movements or the lure of higher incomes in "northern economies"- also desire to maintain close connections with friends and relatives at the place of origin.

\section{THE EMPIRICAL RESEARCH}

The primary data source for numbers of minutes of telephone connection from one country to another is the electronic edition of TeleGeography 2001. In this proprietary information source, traffic statistics were compiled primarily from an independent survey of telecommunications service providers. For some countries and carriers, traffic data were estimated based on annual reports, government publications, and industry reviews. (TeleGeography, 2001e). Traffic on both fixed and mobile networks was included in national totals. Data on the breakdown of numbers of minutes by business or personal use are not available.

\section{Hypothesis 1. The Volume of International Telephone Traffic is Closely Related to Other Indicators of Economic Connectivity: Trade, Migration, and Tourism}

Since international telephone traffic includes both personal and business components, factors such as trade connections to the world economy, as well as individual migration patterns and 
tourist travel should affect the volume of total national telephone communications. It is hypothesized that total volume of international telephone calls is positively correlated with population size (more callers, more calls), volume of trade measured by the sum of merchandise exports and imports, size of the economy (as indicated by gross national income), and total international tourism, both inbound and outbound. This hypothesis was suggested in the Kellerman study (1990), although that empirical analysis was a series of regressions on percentage share of telephone calls to each of 10 nations from the G7 countries with percentage share of exports, imports and arriving tourists for these nations. In the present analysis, the dependent variable is the total number of minutes of outgoing international telephone calls generated by 77 countries in 1999 (Tele- Geography, 2001f). The independent variables include:

- $\quad$ population size in 1999 (World Development Indicators, 2001, Table 1.1)

- $\quad$ sum of the dollar value (F.O.B.) of imports and exports in 1999 (World Development Indicators, 2001, Table 4.5)

- gross national income in 1999 (World Development Indicators, 2001, Table 1.1) which is defined as the "sum of value added by all resident producers plus any product taxes (less subsidies) not included in the valuation of output plus net receipts of primary income"

- total of inbound and outbound tourists in 1997 (World Development Indicators, 1999, Table 6.14) defined as "the number of visitors who travel to a country other than that where they have their usual residences for a period not exceeding 12 months and whose main purpose in visiting is other than an activity remunerated from within the country visited."

Simple correlations are strong between total outgoing minutes and measures of economic activity and connectivity. The correlation between outgoing minutes and gross national income is 0.909 $(\mathrm{p}<.001)$, total value of exports plus imports is $0.903(\mathrm{p}<.001)$ and total number of inbound and outbound tourists is $0.730(\mathrm{p}<.001)$. Population is not correlated with outgoing minutes $\mathrm{r}=$ 0.172 (.089). The best least-squares regression model based on combination of these four independent variables explains the $85.5 \%$ of the variance in the total volume of outgoing international calls by nation with only two variables: gross national income and total number of inbound and outbound tourists (Table 2). 
TABLE 2.-REGRESSION ON TOTAL VOLUME OF OUTGOING INTERNATIONAL CALLS IN MINUTES

\begin{tabular}{lccc}
\hline \hline & $\begin{array}{c}\text { Standardized } \\
\text { coefficient }\end{array}$ & $t$ & Significance \\
\hline Constant & & -0.770 & .444 \\
Gross national income & 0.754 & 12.924 & .000 \\
$\begin{array}{l}\text { Total number of inbound and } \\
\text { outbound tourists }\end{array}$ & 0.234 & 4.015 & .000 \\
\hline
\end{tabular}

A second approach to the analysis of total international phone calls is to standardize the call volume by population size and use calls per capita as the dependent variable. Since population size does not have a close correlation with total volume of calls, this analysis would be expected to come up with similar findings to that of total calls. The independent variables in this second analysis include the total imports and exports per capita, the total gross national income per capita, the total number of tourist visits per capita, and the sum of merchandise exports and imports divided by the value of GDP, an indicator used by the World Bank to portray the extent of integration of the national economy in the world economy. A least-squares regression using these three independent variables accounted for $82 \%$ of the total variance of international calls per capita (Table 3). As in the findings on the unstandardized telephone call volume, integration in the world economy as indicated by both trade and tourism, are very strong predictors of international telephone calls per capita.

TABLE 3.-REGRESSION ON PER CAPITA INTERNATIONAL OUTGOING MINUTES OFTELEPHONE CALLS

\begin{tabular}{lccc}
\hline \hline & $\begin{array}{c}\text { Standardized } \\
\text { coefficient }\end{array}$ & $t$ & Significance \\
\hline Constant & 0.149 & -0.612 & .542 \\
$\begin{array}{l}\text { Trade as a percentage of gross } \\
\text { domestic product }\end{array}$ & 2.029 & .000 \\
$\begin{array}{l}\text { Gross national income per } \\
\text { capita }\end{array}$ & 0.387 & 5.870 & .000 \\
$\begin{array}{l}\text { Total number of inbound and } \\
\text { outbound tourists per capita }\end{array}$ & 0.149 & 2.029 & .046 \\
\hline
\end{tabular}


Hypothesis 2. Nations can be Organized into a Hierarchy Based on the Sending and Receiving of Telephone Calls, with a Small Number of Regional and Global Centers Sending and Receiving a Relatively Greater Number of Calls

Several empirical studies have indicated the existence of a hierarchy of information flows. For example, Graham and Marvin $(1996,2001)$ demonstrated the "dominance" of New York City within outgoing telephone call patterns for the U.S., and Barnett (1999) and also Kellerman (1992) showed the centrality of the United States, the United Kingdom, Germany and France in the international telephone network. Wheeler and Mitchel- son (1989) found strong differences in volumes of exchanges between sending cities, those at higher positions in the American urban hierarchy, and receiving cities: New York City, and secondarily Los Angeles, Chicago, DallasFort Worth, Boston and San Jose, originated far more messages than they received. Similarly, New York City dominated the international information exchange patterns (Mitchelson and Wheeler, 1994).

Using 1999 data collected by TeleGeography (2001f), the top 30 nations are arrayed with respect to outgoing minutes of international calls (Fig. 1). The United States is by far the largest generator of international telephone minutes, with almost 30 million minutes in 1999. The next largest generator of telephone minutes is the United Kingdom with approximately 10 million minutes, followed by Germany, Canada and France. By volume alone, the United States is even more dominant than a "rank-size" rule would project: indeed, from total volume of telephone minutes, the United States resembles a "primate city" in comparison with the United Kingdom, a distinct second.

Pairs of nation-to-nation contacts are also analyzed (Fig. 2). Again, the United States is both a major call generator as well as a call receiver. The nations that exchange the largest number of international telephone calls are the United States and Canada, the United States and Mexico, and the United States and the United Kingdom. These three sets of routes alone account for more than half the total volume of the top 30 international routes, with the U.S.-Canada route alone accounting for one-fourth of all of these combined calls.

A third analysis of the 1999 data portrays nations with net in-flows of calls (that is, where there are more international calls into the country than leaving it) as opposed to net outflows. The Wheeler and Mitchelson study (1989) showed that in the American urban system, New York City had by far the largest volume of net out-flows, and Kellerman (1992) suggested that "core countries" are called more frequently than "small periphery nations" (p. 1997: 176). In the present analysis, the international telephone flows resemble the patterns described by Wheeler and Mitchelson (1989) for the nation: that is, the nations with the largest net outflows of call (with negative numbers in Fig. 3) are the United States, followed by the United Kingdom, Hong Kong, Germany, and Canada. 


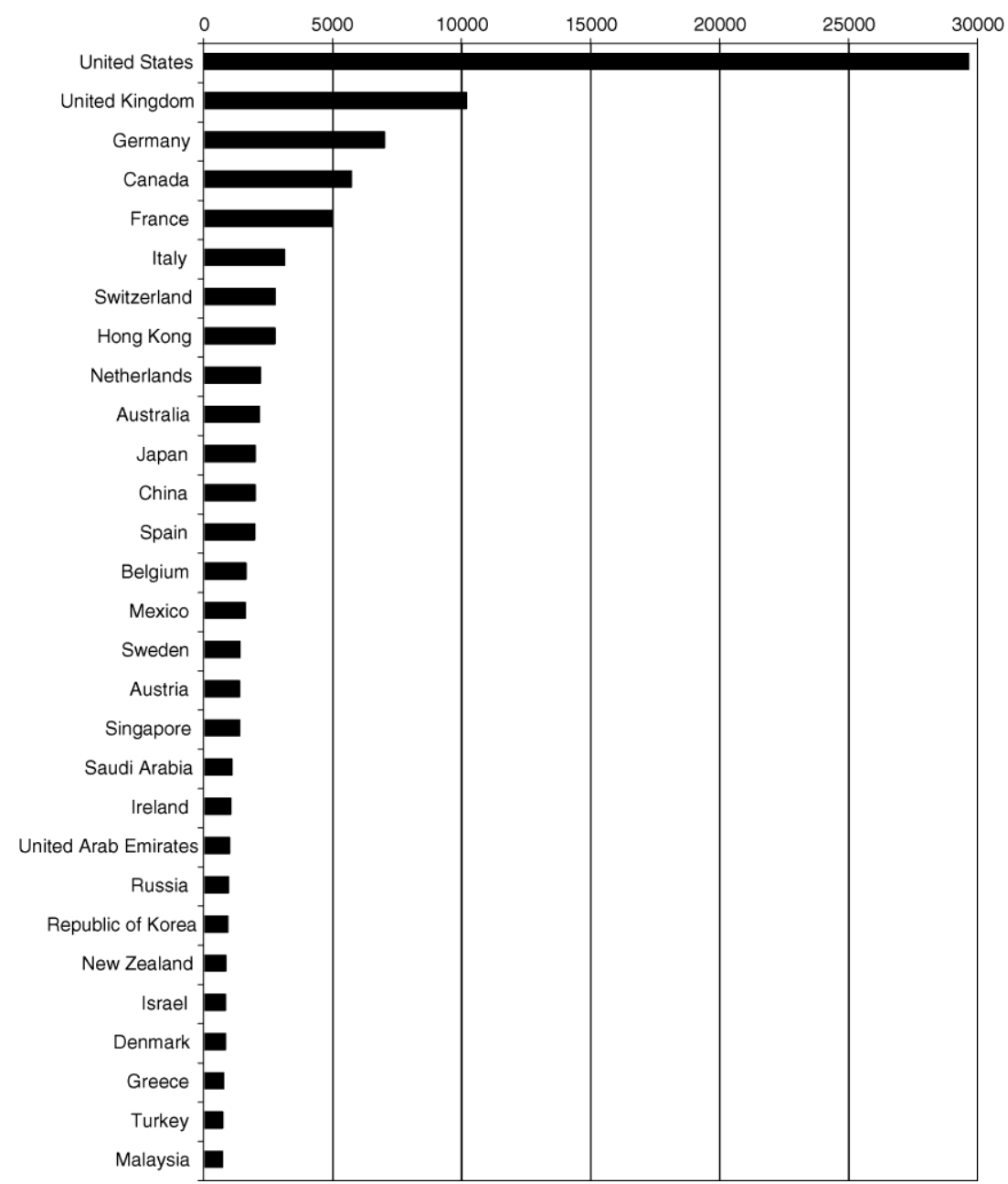

Fig. 1. Outgoing international calls (in millions of minutes), 1999. Note the overwhelming size of international information flow from the United States. Source: TeleGeography, $2001 \mathrm{f}$.

Countries with particularly high net inflows include the Dominican Republic, India, Mexico and Pakistan, countries that receive more messages more than they send.

Hypothesis 3. Distinct Cultural Regions can be Delimited on the Basis of their Calling Partners

To test this hypothesis, a matrix of minutes of outgoing international telephone calls from 136 origins to 136 destinations is analyzed using principal components analysis with a Varimax rotation. The 136 variables were reduced to 36 components with eigen- values of at least 1.00. These 36 components explained $87.7 \%$ of the total variance of the original matrix. Of these, 12 rotated components have eigenvalues of 2.00 or more and, together, account for $57.4 \%$ of the variance, and are described in the following section. Each of these components represents a group of nations with similar international tele- phone call destinations. The reported "loading" of each nation on the components can be interpreted as the simple correlation between the set of 
destinations called from this nation with the combination of destinations called on which that component has been derived. In the following discussion, those nations with factor loadings of .400 or more are listed as representing the cluster of nations summarized by the component (Table 4).

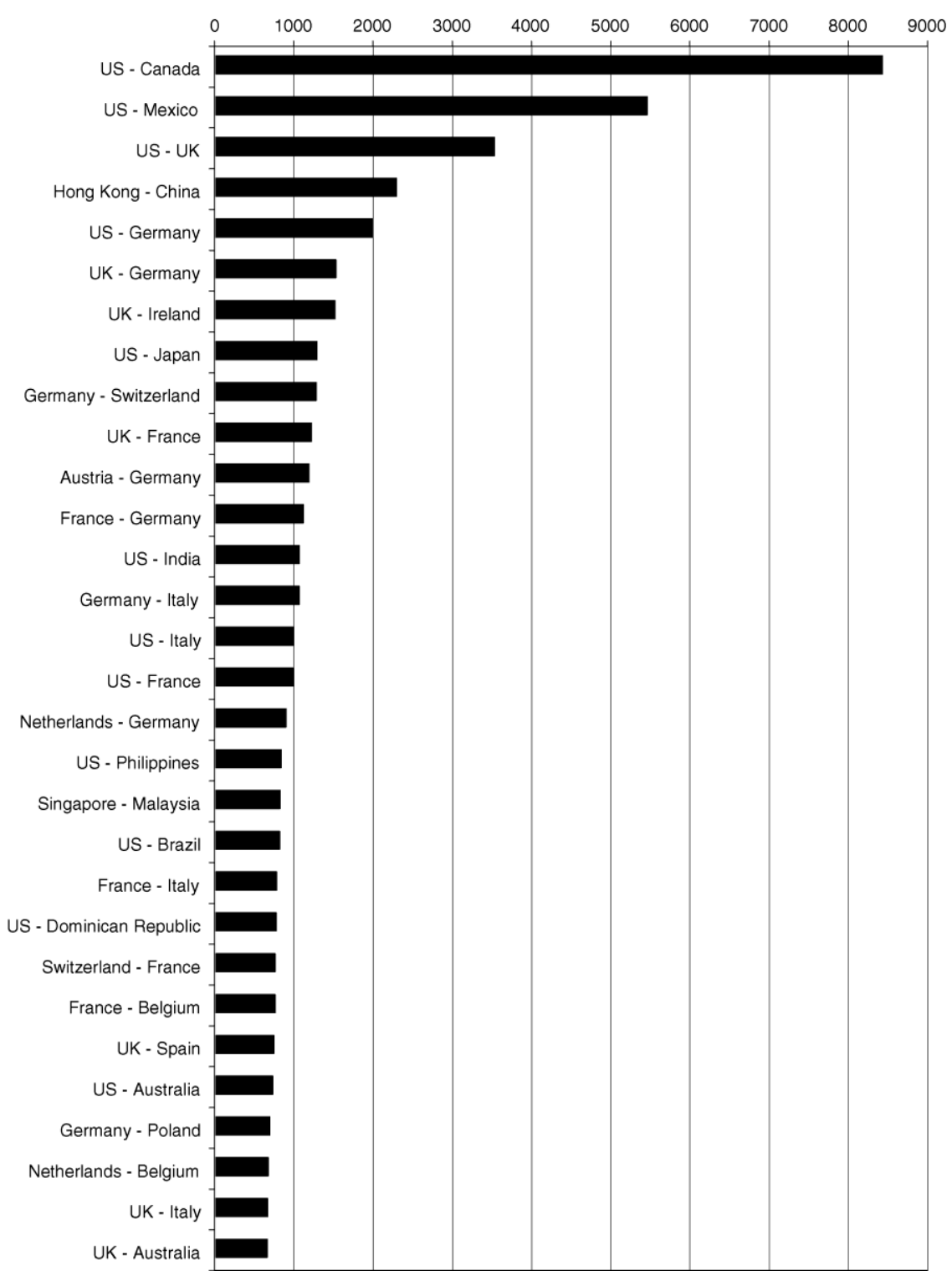

Fig. 2. Largest nation-to-nation routes (in millions of minutes), 1999. The United States is a partner in four of the five largest-volume international pair-wise routes. Source: TeleGeography, 2001f. 


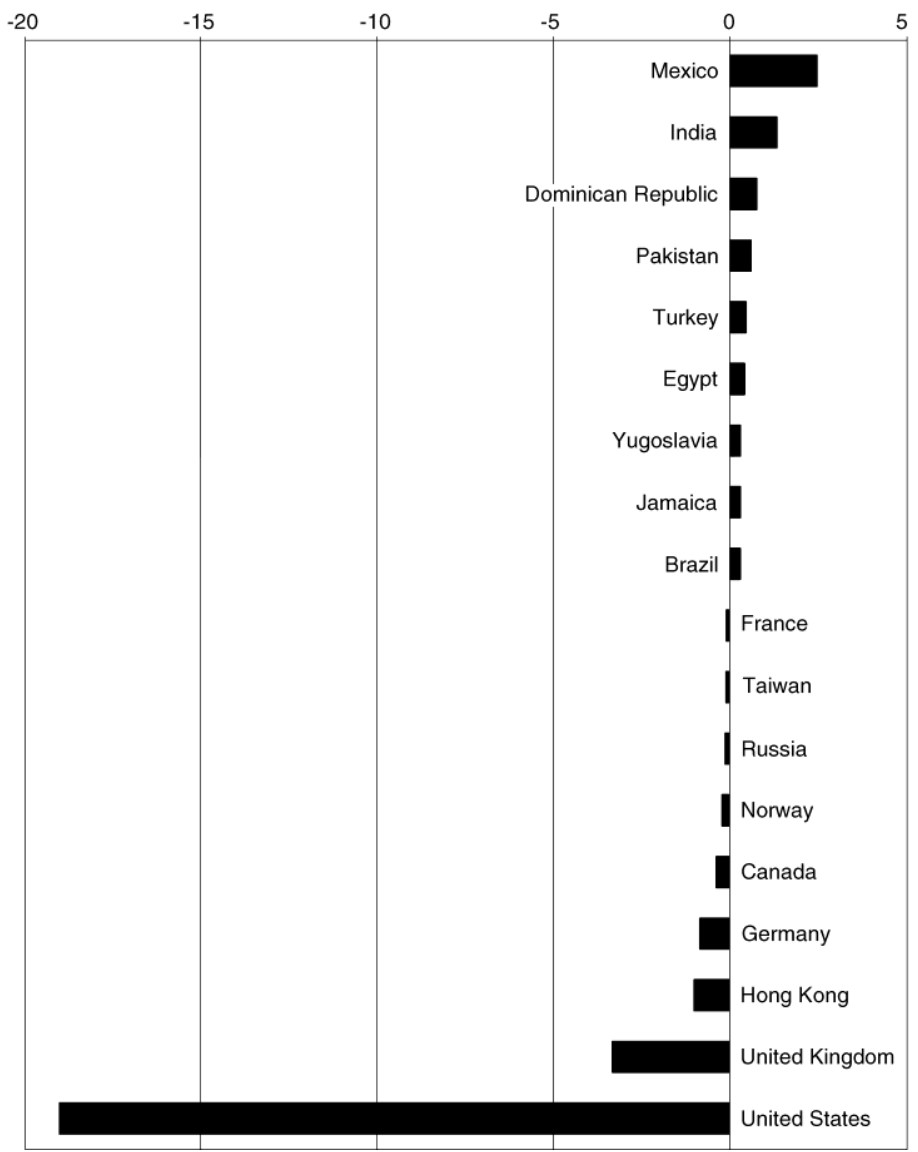

Fig. 3. Incoming calls minus outgoing calls (in thousands of minutes), 1999: a depiction of the "balance of trade" in international telephone calls. Mexico and India, for example, have net outflows of call minutes; the United States, the United Kingdom, and Hong Kong are at the other end of the spectrum, with far more incoming vs. outgoing international call minutes. Source: TeleGeography, $2001 f$.

Factor 1, including the largest number of nations and accounting for $10.8 \%$ of the total variance, groups the countries whose largest outgoing call volumes end in the United States. This is a large and diverse collection of countries, whose connections to the United States involve economic integration and trade (e.g., Canada, Germany, Japan, Korea, Taiwan, the United Kingdom), as well as immigration (e.g., Dominican Republic, Mexico and the Philippines). Other member nations of this group include tourist destinations (e.g., Jamaica), and strategic political and military allies (e.g., Israel). This factor summarizes the call variance of a set of nations with close bilateral relationships with the United States, although not necessarily close associations with one another.

The common calling destination for nations in Factor 2 is Russia, and this cluster includes nations that were once part of the eastern bloc or the Soviet Union. This factor accounts for 7.4\% of the total variance of the full matrix. 
TABLE 4.--RESULTS OF A PRINCIPAL COMPONENTS ANALYSIS OF 136-BY-136 MATRIX OF INTERNATIONAL TELEPHONE CALL MINUTES ${ }^{a}$

\begin{tabular}{|c|c|c|c|c|c|c|c|c|c|c|c|c|}
\hline & Factor 1 & Factor 2 & Factor 3 & Factor 4 & Factor 5 & Factor 6 & Factor 7 & Factor 8 & Factor 9 & Factor 10 & Factor 11 & Factor 12 \\
\hline $\begin{array}{l}\text { Major } \\
\text { destination }\end{array}$ & $\begin{array}{l}\text { United } \\
\text { States }\end{array}$ & Russia & Germany & $\begin{array}{l}\text { Saudi } \\
\text { Arabia }\end{array}$ & $\begin{array}{c}\text { France, } \\
\text { Sub- } \\
\text { Saharan } \\
\text { Africa }\end{array}$ & France & $\begin{array}{c}\text { United } \\
\text { Kingdom }\end{array}$ & $\begin{array}{c}\text { United } \\
\text { States, } \\
\text { Argentina }\end{array}$ & South Africa & $\begin{array}{c}\text { United } \\
\text { States, } \\
\text { Central } \\
\text { America }\end{array}$ & $\begin{array}{c}\text { United } \\
\text { States, } \\
\text { Caribbean }\end{array}$ & India \\
\hline \multirow[t]{19}{*}{$\begin{array}{l}\text { Loadings of } \\
.4 \text { or higher }\end{array}$} & Australia & Armenia & Austria & Bahrain & Benin & Algeria & Australia & Bolivia & Mozambique & El Salvador & Barbados & Bangladesh \\
\hline & Brazil & Azerbaijan & Croatia & Bangladesh & $\begin{array}{c}\text { Burkina } \\
\text { Faso }\end{array}$ & Belgium & France & Chili & Namibia & Honduras & $\begin{array}{c}\text { Cayman } \\
\text { islands }\end{array}$ & Iran \\
\hline & Canada & Belarus & $\begin{array}{c}\text { Czech } \\
\text { Republic }\end{array}$ & Egypt & Cameroon & Luxembourg & Greece & Paraguay & Zimbabwe & Nicaragua & $\begin{array}{c}\text { Trinidad } \\
\text { and Tobago }\end{array}$ & Pakistan \\
\hline & Colombia & Georgia & Denmark & Iran & Gabon & Morocco & Ireland & Peru & Zambia & Panama & $\begin{array}{c}\text { Turk and } \\
\text { Caicos }\end{array}$ & Qatar \\
\hline & $\begin{array}{c}\text { Dominican } \\
\text { Republic }\end{array}$ & Kazakhstan & France & Jordan & Ghana & Portugal & $\begin{array}{c}\text { New } \\
\text { Zealand }\end{array}$ & Uruguay & & & & \\
\hline & France & Kyrgyzstan & Greece & Kuwait & Mali & Spain & Portugal & Venezuela & & & & \\
\hline & Germany & Latvia & Hungary & Lebanon & Nigeria & Switzerland & Spain & & & & & \\
\hline & India & Lithuania & Italy & Oman & Senegal & Tunisia & Switzerland & & & & & \\
\hline & Israel & Moldova & Netherlands & Qatar & Togo & & $\begin{array}{l}\text { Trinidad } \\
\text { and Tobago }\end{array}$ & & & & & \\
\hline & Italy & Ukraine & Poland & Sudan & & & & & & & & \\
\hline & Jamaica & Uzbekistan & Romania & Syria & & & & & & & & \\
\hline & Japan & & Spain & $\begin{array}{l}\text { United Arab } \\
\text { Emirates }\end{array}$ & & & & & & & & \\
\hline & Korea & & Switzerland & Yemen & & & & & & & & \\
\hline & Mexico & & Turkey & & & & & & & & & \\
\hline & Pakistan & & Yugoslavia & & & & & & & & & \\
\hline & Philippines & & & & & & & & & & & \\
\hline & Spain & & & & & & & & & & & \\
\hline & Taiwan & & & & & & & & & & & \\
\hline & $\begin{array}{l}\text { United } \\
\text { Kingdom }\end{array}$ & & & & & & & & & & & \\
\hline $\begin{array}{c}\text { Percentage } \\
\text { of variance } \\
\text { explained }\end{array}$ & 10.84 & 7.41 & 7.03 & 6.61 & 5.46 & 3.88 & 3.45 & 3.37 & 2.86 & 2.30 & 2.09 & 2.07 \\
\hline
\end{tabular}

${ }^{a}$ The 12 dimensions reported here each have eigenvalues of 2.0 or more and represent nations with similar outbound call destinations. 
Nations with higher loadings not only tend to phone Russia overwhelmingly as a common international destination, but are also far more likely than other nations to phone one another. This is a heterogeneous collection of nations: some are overwhelmingly Muslim while others are Orthodox, Roman Catholic or Lutheran. The components of this cluster are Armenia, Azerbaijan, Belarus, Georgia, Kazakhstan, Kyrgyzstan, Latvia, Lithuania, Moldova, Ukraine, and Uzbekistan. Despite its cultural and historical heterogeneity, this cluster of countries can be considered more of a calling community than those in Factor 1 because of their close economic integration as a unit, as well as their historic ties with or as part of the Soviet Union.

Factor 3 accounts for $7.03 \%$ of the total variance and includes countries whose major calling destination is Germany. This cluster includes countries with long cultural relationships with Germany (such as Austria, Denmark, Hungary, the Czech Republic and Switzerland), countries with strong transnational worker ties to Germany (Croatia, Greece, Turkey and Yugoslavia), as well as trading partners such as France, Italy, the Netherlands and Spain. This cluster is also a culturally heterogeneous one, although more diverse than the Russian-oriented cluster and includes at least a few relatively strong competing economies.

Factor 4, which includes most of the Muslim Middle East, clusters nations whose major calling destination is either Egypt or Saudi Arabia. This factor accounts for $6.6 \%$ of the total variance. Component nations of this grouping include Bahrain, Bangladesh, Egypt, Iran, Jordan, Kuwait, Lebanon, Oman, Qatar, Saudi Arabia, Sudan, Syria, United Arab Emirates, and Yemen

Factor 5 includes West African countries, primarily former colonies of France, whose major calls are directed either at France or at other west African nations such as the Ivory Coast. These countries share a dominant role of France as a destination but also as a transmitter of telephone calls to other parts of the world.

Factor 6 are also nations oriented to France, but include nations with very large immigrant populations within France (such as Algeria, Morocco and Tunisia) as well as French-speaking portions of Europe (e.g., Belgium, Luxembourg and Switzerland) and close cultural and economic partners (e.g., Portugal and Spain).

Countries with high loadings on Factor 7 have calls primarily directed to the United Kingdom. This cluster includes Australia, France, Greece, Ireland, New Zealand, Portugal, South Africa, Spain, and Sweden, a set of nations that are major tourist destinations for British citizens (e.g., Greece and Portugal), trading partners (France, Spain and Sweden) or former members of the British Commonwealth (Australia, New Zealand).

Each of factors 8-12 account for less than 3\% of the total variance. Nations loading on Factor 8 include countries whose calls primarily terminate in the United States or Argentina. These are Spanish-speaking South American countries including Bolivia, Chile, Paraguay, Peru, Uruguay and Venezuela. Factor 9 is defined by countries whose telephone calls are oriented to South Africa. It includes nations primarily in the southern-most part of Africa, including Mozambique, 
Namibia, Zimbabwe, and Zambia. Factors 10 and 11 are both centered on the United States but include different clusters of nations. Factor 10 includes Spanish-speaking countries of central America (Honduras, Nicaragua, and Panama) with strong traditional agribusiness ties to the United States, while Factor 11 include several English-speaking nations of the Caribbean (including Barbados, Cayman Islands, Trinidad and Tobago and Turks and Caicos Islands) that are tourist destinations for many Americans. Finally, Factor 12 summarizes the variance of countries with large numbers of calls to India, including Bangladesh, Iran, Pakistan, Qatar, and Saudi Arabia.

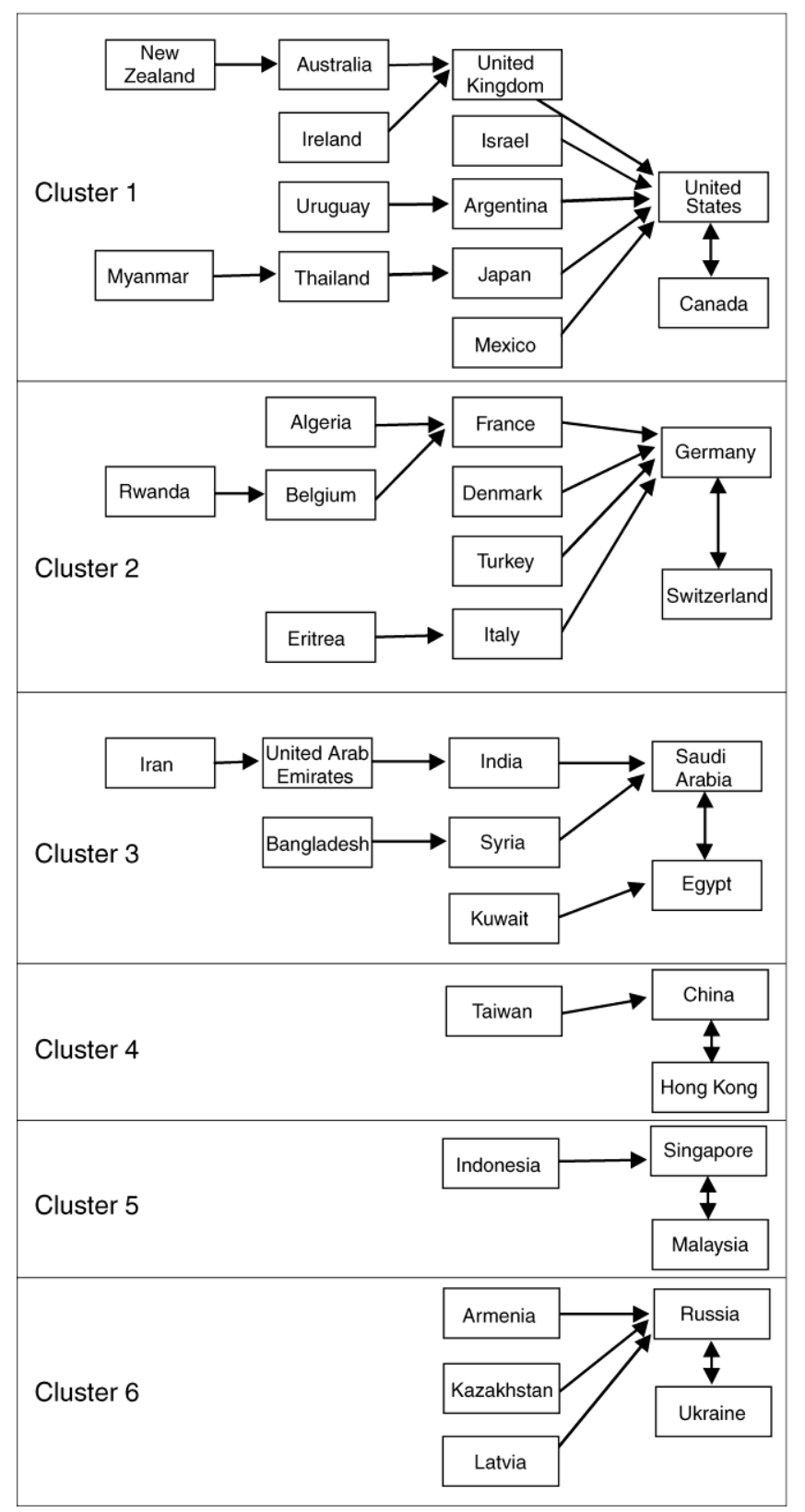

Fig. 4. Clusters of first-order calling partners based on the direction of the largest number of outgoing calls. Calculated by author based on data from TeleGeography 2001. 
These call patterns reflect labor migration (Qatar and Saudi Arabia) as well as traditional strong ties among the neighboring nations of South Asia.

In sum, principal components analysis clearly identifies clusters of nations that have similar international calling patterns, clusters that represent, in part, their social and economic linkages. But principal components analysis is not the only way that clusters of calling partners can be identified. An alternative way to look at the grouping of nations is to analyze the primary or "first-order" calling partner for each country. This analysis yields clusters of all partners, not based on similarity of call patterns, but instead on direction of interaction. To analyze major calling partners, the 136 nations are organized into flow charts based on the direction of largest number of outgoing calls. Using this method, the 136 nations neatly arranged themselves into six discreet first-order calling groups. A simplified and selected version of these six groups is portrayed as Figure 4.

The largest of these call clusters focuses on the United States. Of the 55.5 billion total minutes of calls reported along the 50 highest volume call routes, this cluster accounts for more than 28 billion minutes of calls (more than half of all international call minutes). This cluster includes other nations that are themselves the primary destination for calls from other nations including Japan (primary destination of calls from Thailand), the United Kingdom (primary destination of calls from Australia, Ghana, Gibraltar, Ireland, Malta, Pakistan, South Africa, and Sweden) and Argentina (primary destination for calls from Paraguay and Uruguay). The United States is also the largest call destination of a variety of other nations including: the Bahamas, Bolivia, Brazil, Chile, Costa Rica, Cuba, the Dominican Republic, El Salvador, Ethiopia, Guatemala, Israel, Jamaica, Korea, Mexico, Nicaragua, Panama, Peru, the Philippines, Trinidad, and Venezuela. Nations indirectly connected to the United Kingdom through other call centers are also included such as Swaziland, Zimbabwe and Namibia (whose largest destination was South Africa), New Zealand (primarily connected to Australia), and Finland and Norway (whose primary destination was Sweden).

The second largest call cluster is focused on Germany whose primary call destination is Switzerland. This cluster alone accounts for more than 12 billion call minutes in 1999 or $21.6 \%$ of the total number of minutes of international calls among the top 50 calling routes. Nations whose largest number of call minutes are directed at Germany include central and southern Europe (e.g., Hungary, Poland, Turkey, and Yugoslavia) and countries that were themselves call centers including: France (primary destination for calls from Algeria, Belgium, Benin, Burkina Faso, Chad, Central African Republic, Cote d'Ivoire, French Polynesia, Luxembourg, Madagascar, Mauritius, Mauritania, Morocco, New Caledonia, Niger, Portugal, Senegal, and Togo), Austria (primary destination for calls from Slovenia), Netherlands (primary destination for calls from Suriname), Italy (primary destination for calls from Albania and Eritrea), Spain (primary destination for calls from Andorra), Greece (primary destination for calls from Cyprus and Bulgaria), and the Czech Republic (primary destination for calls from the Slovak Republic). 
Four smaller and more homogeneous call clusters are regionally and culturally based. The first focuses on Saudi Arabia (with its first-order call partner Egypt). This grouping includes Middle Eastern Muslim nations (such as Jordan, Syria, and Sudan) as well as India, itself the primary destination for Bahrain, Bangladesh, Oman, Qatar, Sri Lanka, and the UAR. The second includes the Chinese-speaking nations of China, Hong Kong, Macao and Taiwan. Third are the southeast Asian nations of Brunei, Indonesia, Malaysia and Singapore. Finally, the fourth small cluster centers on Russia, and includes former members of the Soviet Union or closely allied eastern European states such as Armenia, Azerbaijan, Belarus, Georgia, Kazakhstan, Latvia, Moldova, Mongolia, Tajikistan, Turkmenistan, Uzbekistan and Ukraine, Russia's primary calling partner.

To summarize, whether clustered on the basis of similar international calling patterns (through components analysis) or more directly on the basis of first-order calling partners, it is clear that the world is not a single calling community. Clusters or "communities" of telephone flows exist based on regional, cultural and trade relationships. Telephone communication, with all of its characteristics of "cuelessness" and its contingency on common language, culture and/or business interests, rests on a foundation of complex relationships among callers that defy simple notions of "globalization" or "Americanization."

\section{CONCLUSIONS ABOUT TELEPHONE CONNECTIONS}

The possibility of long-distance communication by telephone has been facilitated by a combination of the increasing influence of transnational corporations on the movement of people and messages throughout the world, and the marked improvement in telecommunications technologies and channel capacity. The analysis of outgoing traffic for 136 nations shows that volume of telephone traffic is closely associated with connectivity in other indicators of global economic participation such as volume of international trade, volume of tourist visits and gross national product. A hierarchy of telephone connectivity exists, with nations such as the United Kingdom, the United States, Germany, France and Russia at the center of phone traffic for many trading partners. These nations also generate far more calls to their communication partners than they receive. Finally, there exist "communities of conversation" among the nations of the world, with high levels of conversation within such groupings as the U.S., Japan, the United Kingdom, and North and South America, in contrast with continental Europe focused on Germany, and in contrast still with the Muslim Middle East, the former Soviet Union states, or nations of Chinese

settlement. These communities of conversation are culture realms where messages are frequently exchanged.

Although the findings of a close relationship between call volume and integration into the international economy, as well as the structure of this volume into a national hierarchy may be documentation of what otherwise might have been expected, the finding of clearly discernible and sometimes mutually exclusive calling communities bears further examination. The clear orientation of large portions of the world to former colonial powers (e.g., West Africa and North Africa to France) and the separation of the Muslim Middle East and the Chinese-speaking 
nations of east and Southeast Asia from other calling com- munities, suggest the existence of important continuing historic and cultural influences on information flows in the world economy. The need to understand cultural realms is no less urgent in this day of potential universal and ubiquitous connectivity than it was in the days when various nation-states attempted to set up empires in far-flung corners of the world. This finding of supra-national communities bears further attention as we try to comprehend the changing nature of culture realms in the increasingly interconnected world.

\section{REFERENCES}

Argyle, M., Mansur, L., and Cook, M., 1968, The effects of visibility on interaction in a dyad. Human Relations, Vol. 21, 3-17.

Barnett, G. A., 1999, The Social Structure of International Telecommunications. Progress in Communication Sciences: Advances in Telecommunications Research, Vol. 15, 151-186.

Castells, M., 1989, The Informational City: Information Technology, Economic Restructuring and the Urban-Regional Process. Oxford, UK: Blackwell.

Collinson, S., 1999, Globalisation and the dynamics of international migration: Implications for the refugee regime. New Issues in Refugee Research, Working Paper 1. Retrieved August 20, 2001 from http://www.unhcr.ch/refworld/pub/wpapers/ wpno1.htm.

De Sola Pool, I., 1981, International aspects of telecommunications policy. In M. Moss, editor, Telecommunications and Productivity. Reading, MA: Addison-Wesley.

Dicken, P., 1998, Global Shift: Transforming the World Economy, (3rd ed.). New York, NY: Guilford.

Dodge, M., 1999, Mapping How the Data Flows. Mappa Mundi Magazine. Retrieved January 23, 2002 from http://mappa.mundi.net/maps/maps_004/

Dodge, M., 2001, Flowing from site to site. Mappa Mundi Magazine Retrieved May 2, 2002 from http://mappa.mundi.net/maps/maps_021/

Dodge, M. and Kitchin, R., 2000, Exposing the "second text" in maps of the Network Society. Journal of Computer Mediated Communication, Vol. 5, No. 4. Retrieved January 22, 2002 from. http://www.ascusc.org/jcmc/vol5/issue4/dodge_kitchin.htm

Dodge, M. and Kitchin, R., 2001, Mapping Cyberspace. London, UK, and New York, NY: Routledge.

Dodge, M. and Shiode, N., 2000, Where on earth is the Internet? An empirical investigation of the geography of Internet real estate. In J. O. Wheeler, Y. Aoyama, and B. Warf, editors, Cities in the Telecommunications Age: The Fracturing of Geographies. New York, NY, and London, UK: Routledge, 42-53.

Dumett, S., 1998, Evolution of a wired world: The growth of an undersea, intercontinental network. PreText Magazine. Retrieved January 23, 2002 from http://www.pretext.com/mar98/features/story3.htm

Economic Commission for Africa, 2001, National Information and Communications 
Infrastructure. Retrieved January 22, 2002 from http://www.bellanet.org/partners/aisi/ nici/Default.htm

Graham, S., and Marvin, S., 1996, Telecommunications and the City: Electronic Spaces, Urban Places. New York, NY: Routledge.

Graham, S. and Marvin, S., 2001, Splintering Urbanism: Networked Infrastructures, Technological Mobilities and the Urban Condition. London, UK, and New York, NY: Routledge.

Hardy, S., 1999, Undersea bandwidth prices submerge. Market Intelligence. Retrieved January 232002 from http://www.fiber-exchange.com/archives/market/market_1199.html

Harvey, D., 1989, The Condition of Postmodernity. Oxford, UK: Blackwell.

International Telecommunications Union, 1996, Direction of Traffic, Chapter 2. Retrieved January 22, 2002 from http://www.itu.int/osg/spu/intset/whatare/dot/chap2.html

Internet Traffic Report, 2002. Retrieved September 13, 2001 from http://www.internettrafficreport.com/

Jameson, F., 1991, Postmodernism, or, the Cultural Logic of Late Capitalism. London, UK: Verso.

Johnston, R. J., Taylor, P. J., and Watts, M. J., 1995, Introduction to Part IV: Modernity, Identity, and Machineries of Meaning. In R. J. Johnston, P. J. Taylor, and M. J. Watts, editors, Geographies of Global Change: Remapping the World in the Late Twentieth Century. Oxford, UK: Blackwell, 227-231.

Kellerman, A., 1990, International telecommunications around the world: A flow analysis. Telecommunications Policy, Vol. 14, 461-475.

Kellerman, A., 1992, Telecommunications and Geography. London, UK and New York, NY: Belhaven.

Kelly, P. F., 1999, The geographies and politics of globalization. Progress in Human Geography, Vol. 23, 379-400.

Langdale, J. V., 1989, The geography of international business telecommunications: the role of leased networks. Annals, Association of American Geographers, Vol. 79, 501-522.

Lee, J. R., 2000, Exploring the Gaps: Vital Links between Trade, Environment, and Culture. West Hartford, CT: Kumarian.

Mitchelson, R. L. and Wheeler, J. O., 1994, The flow of information in a global economy: The role of the American urban system in 1990. Annals, Association of American Geographers, Vol. 84, 87-107.

Mittleman, J., 1996, The dynamics of globalization. In J. Mittleman, editor, Globalization: Critical Reflections. London, UK: Lynne Rienner.

Morley, I. E. and Stephenson, G. M., 1977, The Social Psychology of Bargaining. London, UK: Allen \& Unwin.

Murray, M. and Claffy, K. C., 2001, Measuring the Immeasurable: Global Internet Measurement Infrastructure. Retrieved January 22, 2002 from 
http://www.caida.org/outreach/papers/2001/MeasInfra/measurement.pdf

Pauly, L. W. and Reich, S., 1997, National structures and multinational corporate behavior: Enduring differences in an age of globalization. International Organization, Vol. 51, 130.

Rutter, D. R., 1987, Communicating by Telephone. Oxford, UK: Pergamon.

Scheeres, J., 2001, Latin America: the mobile world. Wired News. Retrieved January 22, 2002 from http://www.wired.com/news/technology/0,1282,41309,00.html

Short, J., Williams, E. and Christie, B., 1976, The Social Psychology of Telecommunications. Chichester, UK: Wiley.

Spero, J., 1992, The Politics of International Economic Relations (4th ed.). London, UK: Routledge.

TeleGeography, 2001a, Overview of international traffic trends. TeleGeography 2001 (electronic edition). Washington, DC: Author.

TeleGeography, 2001b, Analysis. TeleGeography 2001 (electronic edition). Washington, DC: Author.

TeleGeography, 2001c, International traffic from mobile phones. TeleGeography 2001 (electronic edition). Washington, DC: Author.

TeleGeography, 2001d, Executive summary. TeleGeography 2001 (electronic edition). Washington, DC: Author.

TeleGeography, 2001e, Methodology. TeleGeography 2001 (electronic edition). Washington, DC: Author.

TeleGeography, 2001f, International traffic statistics. TeleGeography 2001 (electronic edition). Washington, DC: Author.

Thrift, N., 1995, A hyperactive World. In R. J. Johnston, P. J. Taylor, and M. Watts, editors, Geographies of Global Change: Remapping the World in the Late Twentieth Century. Oxford, UK: Blackwell, 18-34.

Traceroute, 2002. http://www.traceroute.org/

Wheeler, J. O., Aoyama, Y., and Warf, B., 2000, Introduction: City Space, Industrial Space and Cyberspace. In J. O. Wheeler, Y. Aoyama, and B. Warf, editors, Cities in the Telecommunications Age: The Fracturing of Geographies. New York, NY and Lon- don, UK: Routledge, 3-17.

Wheeler, J. O. and Mitchelson, R. L., 1989, Information flows among major metropolitan areas in the United States. Annals, Association of American Geographers, Vol. 79, 523-543. 